\author{
JUSTYNA WECGRZYN \\ ORCID: 0000-0002-7996-9441 \\ Uniwersytet Wrocławski \\ Katedra Prawa Konstytucyjnego
}

\title{
ODDZIAŁYWANIE PRAWA DO PRZENOSZENIA DANYCH NA SYTUACJĘ PRAWNĄ KONSUMENTA
}

\begin{abstract}
Abstrakt: Szybki rozwój technologii oraz usług społeczeństwa informacyjnego w ciągu ostatnich lat przyniósł nowe wyzwania w dziedzinie ochrony danych osobowych. Prawodawca unijny stanął więc przed koniecznością dostosowania przepisów prawa między innymi do zdigitalizowanej rzeczywistości, czego potwierdzeniem jest gruntowna reforma w ochronie danych osobowych. Jednym z jej nowych rozwiązań jest prawo do przenoszenia danych, które stanowi przedmiot niniejszych rozważań.
\end{abstract}

Słowa kluczowe: dane osobowe, konsument, administrator, prawo do przenoszenia danych

\section{WPROWADZENIE}

Szybki postęp techniczny oraz powszechny dostęp do Internetu przyczyniły się do zwiększenia skali zbierania i wymiany danych osobowych zarówno przez podmioty publiczne, jak i prywatne. W wypadku tych ostatnich wydaje się, że to one wiodą prym w przetwarzaniu naszych danych osobowych. Przesądza o tym nie tylko wzrastająca liczba dokonywanych czynności prawnych w świecie wirtualnym, lecz także bardzo duże zainteresowanie konsumentów coraz to nowszymi urządzeniami i usługami, które wymagają od nich udostępnienia danych osobowych.

Przykładem są chociażby urządzenia typu wearables, do których zalicza się np. smartwatch (inteligentne zegarki), smartband (inteligentna opaska na rękę, która służy do rejestrowania naszej codziennej aktywności fizycznej), watchband (inteligentna opaska-zegarek), Google Glass. Wśród usług są to natomiast portale społecznościowe, chmury obliczeniowe [czy wypożyczalnie filmów online - J.W. $]^{1}$.

${ }^{1}$ M. Jabłoński, J. Węgrzyn, Zmiana modelu ochrony danych osobowych — podejście oparte na ryzyku, privacy by design $i$ privacy by default, [w:] Reforma ochrony danych osobowych a jawność dostępu do informacji sądowej - aspekty proceduralne, red. M. Jabłoński, K. Flaga-Gieruszyńska, K. Wygoda, Wrocław 2017, s. 75. 
Należy przy tym mieć na uwadze, że obecnie wielu przedsiębiorców oferuje bezpłatny dostęp do wirtualnych usług w zamian za nasze dane, które stają się dla nich cennym towarem. Osoba, której dane dotyczą, bardzo często nie zdaje sobie jednak sprawy, że popularność usługi i darmowy do niej dostęp sprawiają, że przestaje ona mieć kontrolę nad własnymi danymi osobowymi. Aby zapewnić więc wysoki, lecz także spójny stopień ochrony osób fizycznych w związku z przetwarzaniem dotyczących ich danych, konieczne było przeprowadzenie reformy ochrony danych osobowych, której efektem jest — stosowane od 25 maja 2018 roku bezpośrednio we wszystkich państwach członkowskich — rozporządzenie Parlamentu Europejskiego i Rady (UE) 2016/679 z dnia 27 kwietnia 2016 roku w sprawie ochrony osób fizycznych w związku z przetwarzaniem danych osobowych i w sprawie swobodnego przepływu takich danych oraz uchylenia dyrektywy 95/46/WE (ogólne rozporządzenie o ochronie danych $)^{2}$. Rozwiązania wprowadzone tą reformą dotyczą między innymi uwzględniania ochrony danych $\mathrm{w}$ fazie projektowania oraz domyślnej ochrony danych ${ }^{3}$, zgłaszania naruszeń ochrony danych osobowych ${ }^{4}$, oceny skutków ochrony danych $^{5}$, poszerzonego zakresu obowiązków informacyjnych ciążących na administratorach ${ }^{6}$, a także zagwarantowania nowych praw osobie, której dane dotyczą, czego przykładem jest kluczowe dla tych rozważań prawo do przenoszenia danych.

\section{ZAKRES PODMIOTOWY PRAWA DO PRZENOSZENIA DANYCH}

Zgodnie z art. 20 ust. 1 RODO prawo do przenoszenia danych przysługuje osobie, której dane dotyczą. Jest nią wyłącznie osoba fizyczna ${ }^{7}$, albowiem

niniejsze rozporządzenie nie dotyczy przetwarzania danych osobowych dotyczących osób prawnych, w szczególności przedsiębiorstw będących osobami prawnymi, w tym danych o firmie i formie prawnej oraz danych kontaktowych osoby prawnej ${ }^{8}$.

2 Dz.Urz. UE L 119 (dalej: RODO).

${ }^{3} \mathrm{Na}$ ten temat zob. M. Bienias, Ochrona danych $w$ fazie projektowania oraz domyślna ochrona danych (privacy by design oraz privacy by default) $w$ ogólnym rozporzadzeniu o ochronie danych, „Monitor Prawniczy” 2016, nr 20, s. 53 n.; A. Kobylańska, Ł. Ślęzak, Ochrona danych w fazie projektowania - privacy by design, „ABI Expert” 2016, nr 1, s. 15 n.

${ }^{4} \mathrm{Na}$ ten temat zob. P. Fajgielski, Informowanie o naruszeniu ochrony danych osobowych w świetle przepisów ogólnego rozporządzenia o ochronie danych, „Monitor Prawniczy” 2016, nr 20, s. 43 n.; M. Mazur, Zgłaszanie naruszeń ochrony danych, „ABI Expert” 2018, nr 3, s. 22 n.

${ }^{5} \mathrm{Na}$ ten temat zob. A. Mednis, Wymóg oceny skutków przetwarzania w ogólnym rozporzqdzeniu o ochronie danych, „Monitor Prawniczy” 2016, nr 20, s. 29 n.; T. Izydorczyk, Ocena ryzyka naruszenia praw lub wolności osób i ocena skutków dla ochrony danych, [w:] Reforma ochrony danych..., s. $87 \mathrm{n}$.

${ }^{6} \mathrm{Na}$ ten temat zob. K. Wygoda, Przejrzyste informowanie, przejrzysta komunikacja i tryb wykonywania praw - obowiazki administratora danych, [w:] Realizacja praw osób, których dane dotycza, na podstawie RODO, red. B. Fischer, M. Sakowska-Baryła, Warszawa 2017, s. 73 n.

${ }^{7}$ Zob. art. 1 RODO.

${ }^{8}$ Motyw 14 RODO. 
Podmiotem zobowiązanym do realizacji omawianego prawa jest natomiast administrator, którym może być osoba fizyczna lub prawna, organ publiczny, jednostka lub inny podmiot, który samodzielnie lub wspólnie z innymi ustala cele i sposoby przetwarzania danych osobowych. Jeżeli cele i sposoby takiego przetwarzania są określone $\mathrm{w}$ prawie Unii lub w prawie państwa członkowskiego, to również w prawie Unii lub w prawie państwa członkowskiego może zostać wyznaczony administrator lub mogą zostać określone konkretne kryteria jego wyznaczania9.

Wskazany zakres podmiotowy prawa do przenoszenia danych jest szeroki. Biorąc jednak pod uwagę, że podmiot danych, to jest osoba fizyczna, może występować $\mathrm{w}$ różnych rolach społecznych, a jedną z nich jest rola konsumenta, w niniejszej publikacji odnoszę się do relacji zachodzących na linii konsumentprzedsiębiorca (administrator), aby pokazać, jakie znaczenie dla konsumenta ma prawo do przenoszenia danych.

\section{ZAKRES PRZEDMIOTOWY PRAWA DO PRZENOSZENIA DANYCH}

Jak wynika z rozwiązań przyjętych w art. 20 ust. 1 RODO, osoba, której dane dotyczą, ma prawo otrzymać w ustrukturyzowanym, powszechnie używanym formacie nadającym się do odczytu maszynowego dane osobowe jej dotyczące, które dostarczyła administratorowi, oraz ma prawo przesłać te dane osobowe innemu administratorowi bez przeszkód ze strony administratora, któremu dostarczono te dane osobowe, jeżeli:

a) przetwarzanie odbywa się na podstawie zgody w myśl art. 6 ust. 1 lit. a) lub art. 9 ust. 2 lit. a) bądź na podstawie umowy w myśl art. 6 ust. 1 lit. b); oraz

b) przetwarzanie odbywa się w sposób zautomatyzowany.

Odnosząc się do treści wskazanego przepisu, dostrzeżemy, że „zakresem żądania przeniesienia danych objęte są wyłącznie dane osobowe"10 konsumenta,

${ }^{9}$ Art. 4 pkt 7 RODO. Na ten temat zob. K. Witkowska-Nowakowska, Komentarz do art. 4 pkt 7 , [w:] RODO. Ogólne rozporządzenie o ochronie danych, red. E. Bielak-Jomaa, D. Lubasz, Warszawa 2018, s. $211 \mathrm{n}$.

10 Wytyczne Grupy Roboczej Art. 29 dotyczące prawa do przenoszenia danych przyjęte w dniu 13 grudnia 2016 roku, ostatnio zmienione i przyjęte w dniu 5 kwietnia 2017 roku, WP 242, s. 11. Zgodnie z art. 4 pkt 1 RODO „dane osobowe oznaczają informacje o zidentyfikowanej lub możliwej do zidentyfikowania osobie fizycznej (»osobie, której dane dotyczą«); możliwa do zidentyfikowania osoba fizyczna to osoba, którą można bezpośrednio lub pośrednio zidentyfikować, w szczególności na podstawie identyfikatora, takiego jak imię i nazwisko, numer identyfikacyjny, dane o lokalizacji, identyfikator internetowy lub jeden bądź kilka szczególnych czynników określających fizyczną, fizjologiczną, genetyczną, psychiczną, ekonomiczną, kulturową lub społeczną tożsamość osoby fizycznej”. 
które dostarczył on administratorowi ${ }^{11}$. „Ten z pozoru wąski katalog danych” 12 został poddany wykładni rozszerzającej przez Grupę Roboczą Art. 29, która słusznie uznała następujące kategorie danych za „dostarczone” (w tym wypadku przez konsumenta):

— „dane aktywnie i świadomie dostarczone”"13 (na przykład adres e-mail, numer telefonu, imię i nazwisko, wiek);

— ,zaobserwowane dane dostarczone przez osobę, której dane dotyczą [konsumenta - J.W.], poprzez korzystanie z danej usługi lub urządzenia"14 (na przykład urządzenia activity tracker, dane o lokalizacji).

Za dostarczone przez konsumenta nie będą uznane jednak dane wywnioskowane i wywiedzione ${ }^{15}$ przez administratora, którym jest na przykład bank lub przedsiębiorca. Dotyczyć to będzie między innymi oceny zdolności kredytowej konsumenta, wyników algorytmicznych, danych wytworzonych w procesie personalizacji, rekomendacji, kategoryzacji użytkownika lub profilowania ${ }^{16}$.

$\mathrm{Z}$ przyjętych $\mathrm{w}$ art. 20 ust. 1 RODO rozwiązań wynika, że prawo do przenoszenia danych przejawia się także w możliwości przesłania przez konsumenta dotyczących go danych innemu administratorowi bez przeszkód ze strony administratora, któremu pierwotnie dostarczono te dane osobowe. W praktyce oznacza to zakaz wprowadzania przez administratora barier prawnych, technicznych lub finansowych, których efektem byłoby powstrzymywanie lub spowolnienie dostępu, przesyłania lub ponownego wykorzystania przez konsumenta lub innego administratora danych ${ }^{17}$. Do takich przeszkód można zaliczyć na przykład

żądanie wniesienia opłaty z tytułu przekazania danych ${ }^{18}$, brak interoperacyjności lub dostępu do formatu danych, interfejsu programowania aplikacyjnego lub dostarczonego formatu, nadmierna

11 Zakresem żądania przenoszenia danych objęte są także „dane pseudonimiczne, które można jednoznacznie powiązać z osobą, której dane dotyczą (np. poprzez podanie przez nią odpowiedniego identyfikatora)" - wytyczne Grupy Roboczej Art. 29..., s. 11.

12 J. Kaźmierczak, Prawo do przenoszenia danych osobowych - wybrane zagadnienia na tle realizacji nowego uprawnienia przyznanego przez RODO, ,Internetowy Kwartalnik Antymonopolowy i Regulacyjny" 2018, nr 4, s. 90, https://ikar.wz.uw.edu.pl/numery/51/86.pdf.

13 Wytyczne Grupy Roboczej Art. 29..., s. 12.

14 Ibidem.

15 Ibidem.

16 Ibidem. „Profilowanie oznacza dobrowolną formę zautomatyzowanego przetwarzania danych osobowych, które polega na wykorzystaniu danych osobowych do oceny niektórych czynników osobowych osoby fizycznej, w szczególności do analizy lub prognozy aspektów dotyczących efektów pracy tej osoby, jej sytuacji ekonomicznej, zdrowia, osobistych preferencji, zainteresowań, wiarygodności, zachowania, lokalizacji lub przemieszczania się" - art. 4 pkt 4 RODO. Na temat profilowania zob. E. Niezgódka, Definicja i skutki profilowania w przepisach RODO, „ABI Expert” 2018, nr 1, s. 14 n.

17 Wytyczne Grupy Roboczej Art. 29..., s. 18.

$18 \mathrm{~W}$ tym miejscu warto wspomnieć, że działania podejmowane przez administratora w związku z przenoszeniem danych są wolne od opłat, chyba że żądania osoby, której dane dotyczą, są ewidentnie nieuzasadnione lub nadmierne w szczególności ze względu na swój ustawiczny charakter. W takim wypadku administrator może: a) pobrać rozsądną opłatę, uwzględniając administracyjne 
zwłoka lub złożoność w odniesieniu do uzyskania pełnego zbioru danych, celowe zamaskowanie zbioru danych ${ }^{19}$.

Poza wskazanymi uprawnieniami konsument może żądać, aby dotyczące go dane osobowe, które dostarczył administratorowi, zostały przesłane przez tego administratora bezpośrednio innemu administratorowi, o ile jest to technicznie możliwe ${ }^{20}$. Zalecane przy tym jest opracowywanie i stosowanie interoperacyjnych formatów, które umożliwiają przenoszenie danych ${ }^{21}$. $\mathrm{Z}$ bezpośrednim przesłaniem danych będziemy mieli więc do czynienia, gdy możliwa będzie „komunikacja między dwoma systemami w zabezpieczony sposób"22 (na przykład poprzez szyfrowanie danych) oraz gdy system otrzymujący będzie miał „techniczną możliwość odebrania przychodzących danych" ${ }^{23}$. W zaprezentowanym ujęciu prawo, o którym mowa,

ma umożliwić osobom łatwe przenoszenie się pomiędzy podobnymi serwisami lub pomiędzy serwisami wykorzystującymi podobne rozwiązania. Zdaniem rzeczników ochrony danych zapobiegnie to „uzależnieniu” konsumentów od konkretnego serwisu i promować będzie wymianę danych osobowych między administratorami danych w bezpieczny sposób, pod kontrolą osoby, której dane dotyczą ${ }^{24}$.

Aby można było jednak mówić o urzeczywistnieniu przysługującego konsumentowi prawa do przenoszenia dotyczących go danych, konieczne jest ziszczenie się łącznie trzech przesłanek. Pierwsza tyczy się przetwarzania danych zwykłych konsumenta ${ }^{25}$ na podstawie wyrażonej przez niego zgody ${ }^{26}$ lub na podstawie umowy, w odniesieniu zaś do szczególnych kategorii danych ${ }^{27}$ tylko na podstawie zgody $^{28}$. Druga dotyczy zautomatyzowanego sposobu przetwarzania danych ${ }^{29}$.

koszty udzielenia informacji, prowadzenia komunikacji lub podjęcia żądanych działań, albo b) odmówić podjęcia działań w związku z żądaniem. Obowiązek wykazania, że żądanie ma ewidentnie nieuzasadniony lub nadmierny charakter, spoczywa na administratorze — art. 12 ust. 5 RODO.

19 Wytyczne Grupy Roboczej Art. 29..., s. 18.

20 Art. 20 ust. 2 RODO.

21 Motyw 68 RODO.

22 Wytyczne Grupy Roboczej Art. 29..., s. 19.

23 Ibidem.

24 W.R. Wiewiórowski, Prawo do przenoszenia danych w ogólnym rozporządzeniu o ochronie danych osobowych, „Europejski Przegląd Sejmowy” 2017, nr 5, s. 25.

25 Dane zwykłe to na przykład imię i nazwisko, adres zamieszkania, sytuacja majątkowa, waga, wzrost.

${ }^{26} \mathrm{Na}$ temat zgody zob. M. Mazewski, Prawo do wyrażenia $i$ wycofania zgody na przetwarzanie danych, [w:] Realizacja praw..., s. $47 \mathrm{n}$.

27 Dane szczególnej kategorii to dane osobowe ujawniające pochodzenie rasowe lub etniczne, poglądy polityczne, przekonania religijne lub światopoglądowe, przynależność do związków zawodowych, dane genetyczne, dane biometryczne, dane dotyczące zdrowia, seksualność lub orientację seksualną - art. 9 ust. 1 RODO.

28 Zob. art. 20 ust. 1 lit. a) RODO.

29 Zob. art. 20 ust. 1 lit. b) RODO. 
Chodzi przede wszystkim o wszelkie systemy informatyczne, w których dokonywane jest przetwarzanie danych, jak chociażby aplikacje mobilne, oprogramowania, serwisy webowe itp. Tym samym spoza zakresu prawa do przenoszenia danych wyłączono manualne operacje przetwarzania danych ${ }^{30}$.

Z kolei trzecia uzależnia realizację prawa do przenoszenia danych od niewystępowania niekorzystnego wpływu na prawa i wolności innych ${ }^{31}$. Jeśli więc

określony zestaw danych osobowych odnosi się do więcej niż jednej osoby, której dane dotyczą, prawo do otrzymania danych osobowych nie powinno powodować uszczerbku dla praw i wolności innych osób, których dane dotyczą 32 .

\section{Nie budzi zatem wątpliwości, że z naruszeniem praw i wolności osób trzecich będziemy mieli do czynienia,}

jeżeli nowy administrator danych wykorzysta dane osobowe do innych celów, np. jeżeli otrzymujący administrator danych wykorzysta dane osobowe innych osób fizycznych figurujących w spisie kontaktów osoby, której dane dotyczą, do celów marketingowych. W związku z tym, aby zapobiec wywarciu niekorzystnego wpływu na zaangażowane osoby trzecie, przetwarzanie takich danych osobowych przez innego administratora jest dopuszczalne wyłącznie w zakresie, w jakim dane są przechowywane pod wyłączną kontrolą użytkownika wnoszącego żądanie i są zarządzane wyłącznie w celu zaspokojenia potrzeb o czysto osobistym lub domowym charakterze. Otrzymujący „,nowy” administrator danych (któremu dane mogą zostać przesłane na żądanie użytkownika) nie może wykorzystywać przesłanych danych osób trzecich do własnych celów, np. w celu oferowania produktów i usług marketingowych tym innym osobom, których dane dotyczą, będącym osobami trzecimi. Przykładowo informacji tych nie należy wykorzystywać do wzbogacenia profilu osoby trzeciej, której dane dotyczą, oraz do odbudowy jej środowiska społecznego, bez jej wiedzy i zgody. Nie można ich również wykorzystywać w celu uzyskania informacji na temat takich osób trzecich oraz tworzenia określonych profili, nawet jeżeli

30 J. Kaźmierczak, op. cit., s. 89.

31 Zob. art. 20 ust. 4 RODO.

32 Motyw 68 RODO. W tym miejscu warto wspomnieć, że konsument inicjujący „przesyłanie swoich danych innemu administratorowi danych udziela zgody na przetwarzanie danych nowemu administratorowi danych albo zawiera umowę z tym administratorem. Jeżeli dane osobowe osób trzecich są zawarte w zbiorze danych, należy określić inną podstawę prawną przetwarzania. Przykładowo prawnie uzasadniony interes może być realizowany przez administratora danych na mocy art. 6 ust. 1 lit. f), w szczególności gdy celem administratora danych jest świadczenie usługi na rzecz osoby, której dane dotyczą, a usługa ta umożliwia wspomnianej osobie przetwarzanie danych osobowych w ramach czynności o czysto osobistym lub domowym charakterze" - wytyczne Grupy Roboczej Art. 29..., s. 13. „Jako przykład może posłużyć przenoszenie danych zawartych w elektronicznych skrzynkach pocztowych. Opracowywane w ramach usługi poczty e-mail książki kontaktowe zawierające dane znajomych, krewnych, rodziny osoby przenoszącej dotyczą i są tworzone przez możliwą do zidentyfikowania osobę, która chce realizować swoje prawo do przenoszenia danych. Administratorzy danych powinni przesłać wszystkie dane osobie, której dane dotyczą. Osoba, której dane dotyczą, będzie przetwarzała dane osobowe w ramach czynności o czysto osobistym lub domowym charakterze, zatem do przetwarzania przez nią danych osobowych, zgodnie $\mathrm{z}$ art. 2 ust. 2 lit. c), rozporządzenie nie ma zastosowania. Jeżeli dane osób trzecich zwarte w przenoszonych książkach kontaktowych są wykorzystywane w tym samym celu podczas procesu przetwarzania u nowego administratora, nie będzie miało to negatywnego wpływu na prawa i wolności tych osób" - A. Gryszczyńska, Prawo do przenoszenia danych osobowych, [w:] Realizacja praw..., s. 270. 
ich dane osobowe znajdują się już w posiadaniu administratora danych. W przeciwnym razie istnieje prawdopodobieństwo, że takie przetwarzanie będzie niezgodne z prawem i nieuczciwe, w szczególności jeżeli osoby trzecie, których sprawa dotyczy, nie są o tym poinformowane i nie mogą wykonywać uprawnień przysługujących im jako osobom, których dane dotyczą ${ }^{33}$.

Mając to na względzie, nie budzi wątpliwości, że zakresem prawa do przenoszenia danych objęte są na przykład tytuły książek nabytych przez konsumenta w księgarni internetowej, listy filmów lub utworów muzycznych oglądanych albo słuchanych za pośrednictwem serwisów streamingowych, listy kontaktów z aplikacji webmail, informacje na temat zakupów dokonanych przy użyciu kart lojalnościowych, historia transakcji bankowych dokonanych przez konsumenta czy informacje o ilości zużytego gazu ${ }^{34}$. Ważne jest przy tym, aby konsument otrzymał dotyczące go dane osobowe w ustrukturyzowanym, powszechnie używanym formacie nadającym się do odczytu maszynowego ${ }^{35}$. Zastosowanie odpowiedniego formatu zależeć będzie od branży (na przykład branża bankowa). W sytuacji jednak gdy

żadne formaty nie są powszechnie używane w danej branży lub w określonym kontekście, administratorzy danych powinni przekazać dane osobowe w powszechnie używanych formatach otwartych (np. XML, JSON, CSV itd.) wraz z przydatnymi metadanymi o najwyższym możliwym poziomie szczegółowości przy jednoczesnym zachowaniu wysokiego poziomu abstrakcji. Odpowiednie metadane należy jako takie wykorzystywać w celu prawidłowego opisania znaczenia informacji będących przedmiotem wymiany. Takie metadane powinny być wystarczające dla umożliwienia funkcjonowania i ponownego wykorzystywania danych, jednak oczywiście bez ujawniania tajemnicy handlowej ${ }^{36}$.

33 Wytyczne Grupy Roboczej Art. 29..., s. 14. Zob. M. Czerniawski, Komentarz do art. 20, [w:] RODO. Ogólne Rozporządzenie..., s. 552.

34 Zob. wytyczne Grupy Roboczej Art. 29..., s. 5 n. Por. P. Litwiński, P. Barta, M. Kawecki, Rozporządzenie UE $w$ sprawie ochrony osób fizycznych $w$ zwiazku z przetwarzaniem danych osobowych i swobodnym przepływem takich danych. Komentarz, red. P. Litwiński, Warszawa 2018, s. 417 n.

35 Pojęcie „format nadający się do odczytu maszynowego" nie zostało w żaden sposób dookreślone w RODO. Pewnych wskazówek interpretacyjnych tego pojęcia można poszukiwać w odrębnych regulacjach prawnych, do których zalicza się dyrektywę Parlamentu Europejskiego i Rady 2013/37/UE z 26 czerwca 2013 roku, zmieniającą dyrektywę 2003/98/WE w sprawie ponownego wykorzystywania informacji sektora publicznego (Dz.Urz. UE L 175). W motywie 21 tej dyrektywy prawodawca unijny wskazał, że „Dokument należy uznać za sporządzony w formacie przeznaczonym do odczytu komputerowego, jeżeli występuje w formacie pliku zorganizowanego w sposób umożliwiający aplikacjom komputerowym łatwe identyfikowanie, rozpoznawanie i pozyskiwanie z niego określonych danych. Dane zakodowane w plikach zorganizowanych w formacie przeznaczonym do odczytu komputerowego to dane przeznaczone do odczytu komputerowego. Formaty przeznaczone do odczytu komputerowego mogą być otwarte lub zastrzeżone; mogą one występować jako standardy formalne lub nie. Dokumentów zakodowanych w formacie pliku ograniczającym przetwarzanie automatyczne z powodu niemożności pozyskania danych lub utrudnień $\mathrm{w}$ ich pozyskaniu $\mathrm{z}$ tych dokumentów nie należy uznawać za sporządzone $\mathrm{w}$ formacie przeznaczonym do odczytu komputerowego. Państwa członkowskie powinny w stosownych przypadkach zachęcać do korzystania z formatów otwartych przeznaczonych do odczytu komputerowego". Mając to na względzie, wydaje się, że można przyjąć, iż format nadający się do odczytu maszynowego to format, który można odczytać na komputerze.

36 Wytyczne Grupy Roboczej Art. 29..., s. 21. 
Zatem aby konsument mógł skutecznie i sprawnie korzystać z prawa do przenoszenia danych, „dane otrzymane od administratora powinny być przygotowane w taki sposób, aby możliwe było ich zaimportowanie do innej aplikacji lub oprogramowania za pomocą prostej opcji »otwórz plik«/»importuj dane «"37. W przeciwnym razie, to jest — gdy administrator użyje skomplikowanego formatu, ponowne wykorzystanie danych przez konsumenta może okazać się niemożliwe.

\section{PRAWO DO PRZENOSZENIA DANYCH A PRAWO DO USUNIĘCIA DANYCH (,PRAWO DO BYCIA ZAPOMNIANYM”)}

Zgodnie z art. 20 ust. $3 \mathrm{zd} .1$ RODO wykonanie prawa do przenoszenia danych pozostaje bez uszczerbku dla prawa do ich usunięcia ${ }^{38}$. Skorzystanie przez konsumenta z możliwości przeniesienia danych nie w każdym przypadku będzie jednak skutkować ich usunięciem. Jeżeli bowiem konsument, przenosząc swoje dane, nie cofnie zgody na ich przetwarzanie lub nie rozwiąże zawartej uprzednio umowy, dotychczasowy administrator będzie mógł nadal przetwarzać dane osobowe konsumenta. $Z$ zupełnie inną sytuacją będziemy mieli do czynienia, gdy konsument skutecznie wystąpi z żądaniem przeniesienia jego danych i żądaniem ich usunięcia. W takim przypadku, co wynika z art. 17 ust. 2 i $3^{39}$ RODO, dotychczasowy administrator powinien poinformować administratorów, którym przekazał dane osobowe konsumenta, że żąda on (konsument) usunięcia łączy do dotyczących go danych, kopii tych danych lub ich replikacji. Nowy administrator, to znaczy ten, który otrzymał dane na drodze przenoszenia, nie będzie związany żądaniem usunięcia danych osobowych, o ile przetwarza dane na podstawie udzielonej przez konsumenta zgody — art. 6 ust. 1 lit. a) lub art. 9 ust. 2 lit. a) RODO bądź zawartej

37 J. Kaźmierczak, op. cit., s. 93.

38 Zob. K. Wygoda, Komentarz do art. 20, [w:] Ogólne rozporządzenie o ochronie danych osobowych. Komentarz, red. M. Sakowska-Baryła, Warszawa 2018, s. 258 n.

39 Art. 17 ust. 2 RODO: „Jeżeli administrator upublicznił dane osobowe, a na mocy ust. $1 \mathrm{ma}$ obowiązek usunąć te dane osobowe, to - biorąc pod uwagę dostępną technologię i koszt realizacji - podejmuje rozsądne działania, w tym środki techniczne, by poinformować administratorów przetwarzających te dane osobowe, że osoba, której dane dotyczą, żąda, by administratorzy ci usunęli wszelkie łącza do tych danych, kopie tych danych osobowych lub ich replikacje”. Ust. 3: „Ust. 1 i 2 nie mają zastosowania w zakresie, w jakim przetwarzanie jest niezbędne: a) do korzystania z prawa do wolności wypowiedzi i informacji; b) do wywiązania się z prawnego obowiązku wymagającego przetwarzania na mocy prawa Unii lub prawa państwa członkowskiego, któremu podlega administrator, lub do wykonania zadania realizowanego $\mathrm{w}$ interesie publicznym lub w ramach sprawowania władzy publicznej powierzonej administratorowi; c) z uwagi na względy interesu publicznego w dziedzinie zdrowia publicznego zgodnie z art. 9 ust. 2 lit. h) oraz i) i art. 9 ust. 3; d) do celów archiwalnych w interesie publicznym, do celów badań naukowych lub historycznych lub do celów statystycznych zgodnie $\mathrm{z}$ art. 89 ust. 1, o ile prawdopodobne jest, że prawo, o którym mowa w ust. 1, uniemożliwi lub poważnie utrudni realizację celów takiego przetwarzania; lub e) do ustalenia, dochodzenia lub obrony roszczeń". 
umowy (art. 6 ust. 1 lit. b) RODO. Powinien on jednak sprawdzić, czy przekazane przez dotychczasowego administratora dane konsumenta są adekwatne do celów,

dla których zostały pozyskane, i usunąć te, których przetwarzanie w jego sytuacji jest niedopuszczalne (dotyczy tzw. minimalizacji danych). Ponadto powinien dokonać ich weryfikacji w celu zidentyfikowania danych nieprawidłowych, aby zostały usunięte lub skorygowane ${ }^{40}$.

Poza tym niewykluczona jest również sytuacja, kiedy konsument wystąpi z żądaniem przeniesienia jego danych i żądaniem ich usunięcia, jednak to ostatnie żądanie nie będzie mogło zostać zrealizowane. $Z$ sytuacją taką będziemy mieli do czynienia, gdy dotychczasowy administrator przetwarzający dane osobowe konsumenta, na przykład w związku z zawartą umową o świadczenie usługi streamingowej, będzie mógł przetwarzać te dane nawet po rozwiązaniu umowy - na podstawie przesłanki wyrażonej w art. 17 ust. 3 lit. b) RODO, to jest wywiązania się administratora z obowiązku prawnego przewidzianego w prawie państwa członkowskiego. Przykładem realizacji tej przesłanki jest wynikający z przepisów podatkowych obowiązek przechowywania faktur — w tym wypadku za świadczenie usługi streamingowej.

\section{PODSUMOWANIE}

Nie ulega wątpliwości, że świat wirtualny, z którego na co dzień korzystamy, daje nam wiele możliwości, ale stwarza też wiele zagrożeń. Udostępniając bowiem dane osobowe na swój temat, często tracimy nad nimi kontrolę. Aby „,»przywrócić równowagę « w stosunkach między osobami, których dane dotyczą [w tym przypadku konsumentami - J.W.] i administratorami" ${ }^{41}$, prawodawca unijny zagwarantował konsumentowi nieznane do tej pory prawo do przenoszenia danych. Zapewnia ono temu podmiotowi między innymi pobranie danych $\mathrm{z}$ jednego serwisu internetowego i przeniesienie ich do drugiego

niezależnie od właściciela usługi i stosowanych w niej rozwiązań technicznych — dzięki możliwości uzyskania danych w postaci elektronicznej w zapisanych jednym z powszechnie używanych formatów. Ma to ułatwić swoistą „mobilność” elektroniczną i zapobiegać zamykaniu serwisów poprzez zaszywanie danych w sposób uniemożliwiający ich ponowne użycie przez samą osobę, której dane dotyczą ${ }^{42}$.

Należy jednak pamiętać, że skorzystanie z tego prawa uzależnione jest od spełnienia wyrażonych w art. 20 RODO przesłane ${ }^{43}$. Z punktu widzenia konsumenta

40 T. Radziszewski, Charakter prawa do przenoszenia danych, [w:] Reforma ochrony..., s. $70 \mathrm{n}$.

41 Wytyczne Grupy Roboczej Art. 29..., s. 4.

42 W.R. Wiewiórowski, op. cit., s. 24.

$43 \mathrm{~W}$ tym miejscu należy zaznaczyć, że prawo do przenoszenia danych nie ma zastosowania do przetwarzania, które jest niezbędne do wykonania zadania realizowanego $\mathrm{w}$ interesie publicznym lub w ramach sprawowania władzy publicznej powierzonej administratorowi - art. 20 ust. 3 zd. 2 RODO. 
ważne jest także, że administrator został zobowiązany do udzielenia konsumentowi informacji o działaniach podjętych w związku z żądaniem realizacji prawa do przenoszenia danych, bez zbędnej zwłoki, a w każdym razie w terminie miesiąca od otrzymania żądania. $\mathrm{W}$ razie potrzeby termin ten może zostać przedłużony o kolejne dwa miesiące $\mathrm{z}$ uwagi na skomplikowany charakter żądania, jeżeli konsument $\mathrm{w}$ terminie miesiąca od dnia wniesienia $\mathrm{z}$ żądania — zostanie poinformowany o takim przedłużeniu, z podaniem przyczyn opóźnienia ${ }^{44}$. Jeżeli jednak administrator nie podejmie działań w związku żądaniem konsumenta, to niezwłocznie (najpóźniej w terminie miesiąca od otrzymania żądania) informuje on konsumenta o powodach niepodjęcia działań oraz o możliwości wniesienia skargi do organu nadzorczego i skorzystania ze środków ochrony prawnej przed sądem ${ }^{45}$. Przy czym wszelka komunikacja administratora z konsumentem ma być prowadzona w zwięzłej, przejrzystej, zrozumiałej i łatwo dostępnej formie, jasnym i prostym językiem ${ }^{46}$.

Mając na względzie wskazane rozwiązania, można stwierdzić, że prawo do przenoszenia danych ma się przyczynić do wzmocnienia pozycji konsumenta ze względu na ułatwienie mu przekazywania dotyczących go danych osobowych między środowiskami IT ${ }^{47}$. Dzięki temu rozwiązaniu konsument będzie mógł osobiście zarządzać własnymi danymi i ponownie je wykorzystywać — oczywiście, o ile spełnione zostaną przesłanki, o których mowa w art. 20 RODO — co ma zapobiec jego uzależnieniu od jednego dostawcy (administratora) i dać mu (konsumentowi) większą kontrolę nad swoimi danymi. Wydaje się, że w praktyce konsumenci nie powinni mieć problemu z realizacją tego prawa, albowiem za jego naruszenie przewidziano karę pieniężną w wysokości do 20 milionów euro, a w wypadku przedsiębiorstwa w wysokości do $4 \%$ jego całkowitego rocznego światowego obrotu z poprzedniego roku obrotowego, przy czym zastosowanie ma kwota wyższa ${ }^{48}$.

\section{THE IMPACT OF THE RIGHT TO DATA PORTABILITY REGARDING THE CONSUMER'S LEGAL SITUATION}

\section{Summary}

The rapid advancement of technologies and information society services in recent years has brought new challenges for the protection of personal data. The EU legislator therefore faced the necessity to adjust the provisions, including to a digitised reality, which is confirmed by a thorough reform of the protection of personal data. One of its new solutions is the right of data portability, which is the subject of these considerations.

Keywords: personal data, consumer, controller, right to data portability

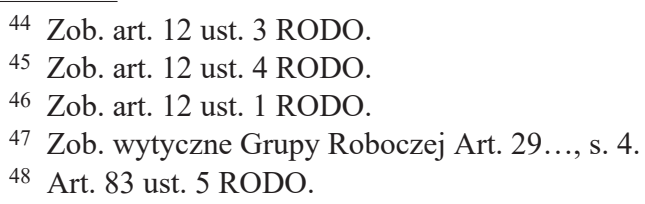




\section{BIBLIOGRAFIA}

Bienias M., Ochrona danych w fazie projektowania oraz domyślna ochrona danych (privacy by design oraz privacy by default) $w$ ogólnym rozporządzeniu o ochronie danych, „Monitor Prawniczy” 2016, nr 20.

Czerniawski M., Komentarz do art. 20, [w:] RODO. Ogólne Rozporządzenie o ochronie danych. Komentarz, red. E. Bielak-Jomaa, D. Lubasz, Warszawa 2018.

Fajgielski P., Informowanie o naruszeniu ochrony danych osobowych w świetle przepisów ogólnego rozporzadzenia o ochronie danych, „Monitor Prawniczy” 2016, nr 20.

Gryszczyńska A., Prawo do przenoszenia danych osobowych, [w:] Realizacja praw osób, których dane dotycza, na podstawie RODO, red. B. Fischer, M. Sakowska-Baryła, Wrocław 2017.

Izydorczyk T., Ocena ryzyka naruszenia praw lub wolności osób i ocena skutków dla ochrony danych, [w:] Reforma ochrony danych osobowych a jawność dostęu do informacji sądowej - aspekty proceduralne, red. M. Jabłoński, K. Flaga-Gieruszyńska, K. Wygoda, Wrocław 2017.

Jabłoński M., Węgrzyn J., Zmiana modelu ochrony danych osobowych - podejście oparte na ryzyku, privacy by design $i$ privacy by default, [w:] Reforma ochrony danych osobowych a jawność dostępu do informacji sądowej — aspekty proceduralne, red. M. Jabłoński, K. Flaga-Gieruszyńska, K. Wygoda, Wrocław 2017.

Kaźmierczak J., Prawo do przenoszenia danych osobowych - wybrane zagadnienia na tle realizacji nowego uprawnienia przyznanego przez RODO, „Internetowy Kwartalnik Antymonopolowy i Regulacyjny" 2018, nr 4, https://ikar.wz.uw.edu.pl/numery/51/86.pdf.

Kobylańska A., Ślęzak Ł., Ochrona danych $w$ fazie projektowania — privacy by design, „ABI Expert” 2016, nr 1.

Litwiński P., Barta P., Kawecki M., Rozporządzenie UE w sprawie ochrony osób fizycznych w zwiazku z przetwarzaniem danych osobowych i swobodnym przeptywem takich danych. Komentarz, red. P. Litwiński, Warszawa 2018.

Mazewski M., Prawo do wyrażenia i wycofania zgody na przetwarzanie danych, [w:] Realizacja praw osób, których dane dotycza, na podstawie RODO, red. B. Fisher, M. Sakowska-Baryła, Wrocław 2017.

Mazur M., Zgłaszanie naruszeń ochrony danych, „ABI Expert” 2018, nr 3.

Mednis A., Wymóg oceny skutków przetwarzania w ogólnym rozporządzeniu o ochronie danych, „Monitor Prawniczy” 2016, nr 20.

Niezgódka E., Definicja i skutki profilowania w przepisach RODO, „ABI Expert” 2018, nr 1.

Radziszewski T., Charakter prawa do przenoszenia danych, [w:] Reforma ochrony danych osobowych a jawność dostępu do informacji sadowej - aspekty proceduralne, red. M. Jabłoński, K. Flaga-Gieruszyńska, K. Wygoda, Wrocław 2017.

Wiewiórowski W.R., Prawo do przenoszenia danych w ogólnym rozporządzeniu o ochronie danych osobowych, „Europejski Przegląd Sejmowy”2017, nr 5.

Witkowska-Nowakowska K., Komentarz do art. 4 pkt 7, [w:] RODO. Ogólne rozporzadzenie o ochronie danych, red. E. Bielak-Jomaa, D. Lubasz, Warszawa 2018.

Wygoda K., Komentarz do art. 20, [w:] Ogólne rozporzadzenie o ochronie danych osobowych. Komentarz, red. M. Sakowska-Baryła, Warszawa 2018.

Wygoda K., Przejrzyste informowanie, przejrzysta komunikacja i tryb wykonywania praw - obowiazki administratora danych, [w:] Realizacja praw osób, których dane dotycza, na podstawie RODO, red. B. Fischer, M. Sakowska-Baryła, Warszawa 2017. 